06

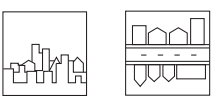

\title{
A STEP TOWARDS AN ENJOYABLE CITY
}

\section{Joining Expertise in Redesigning Public Space Along the "Main Street" in Tallinn}

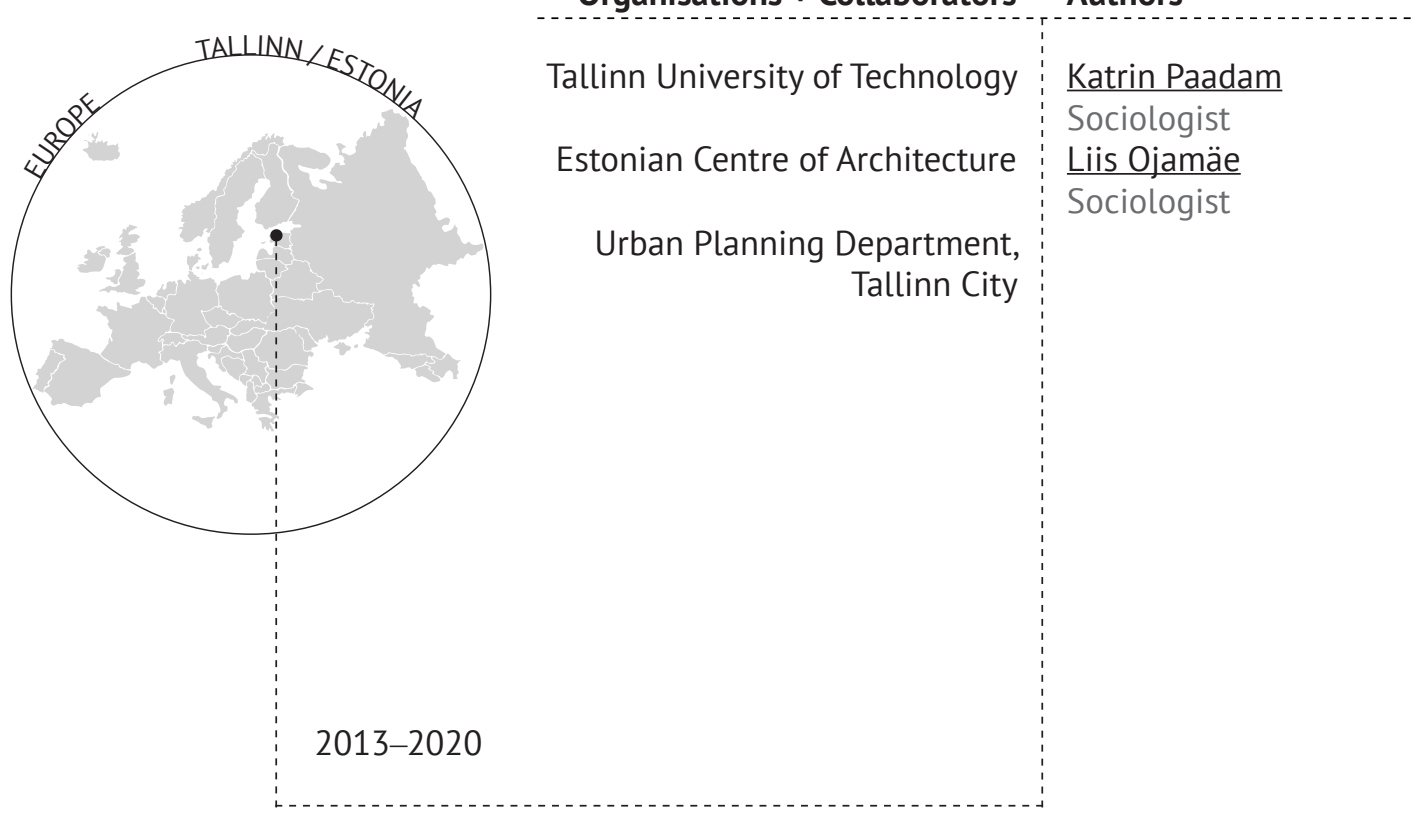

\section{Introduction}

"How to act in a situation where you feel that things are not right, when you know that something has to change and you have a wish to do better? When you have a perception of a goal but you find yourself on an entirely untrodden path?” (Sild, 2017, p. 21). These were the questions the coordinator admits having faced at the outset of the urban renewal project "Main Street" in Tallinn. ${ }^{1}$

The project was given a somewhat symbolic name, "Main Street" (Tallinna Peatänav, as in Figure II.6.2), to manifest a new strategy for the liberation of space in the central city, where two roads are heavily packed with public and car transport stretching along the east-west axis, disruptively joined by an intensive traffic junction in the middle. The adjacent medieval Old Town (Vanalinn, as in Figure II.6.2) and the developing urban waterfront with the harbour area (Sadam in Figure II.6.2) to the north only emphasised the urge for intervention.

FIGURE II.6.1 The Main Street in anticipation of redesign. Photo by Tiit Sild. 


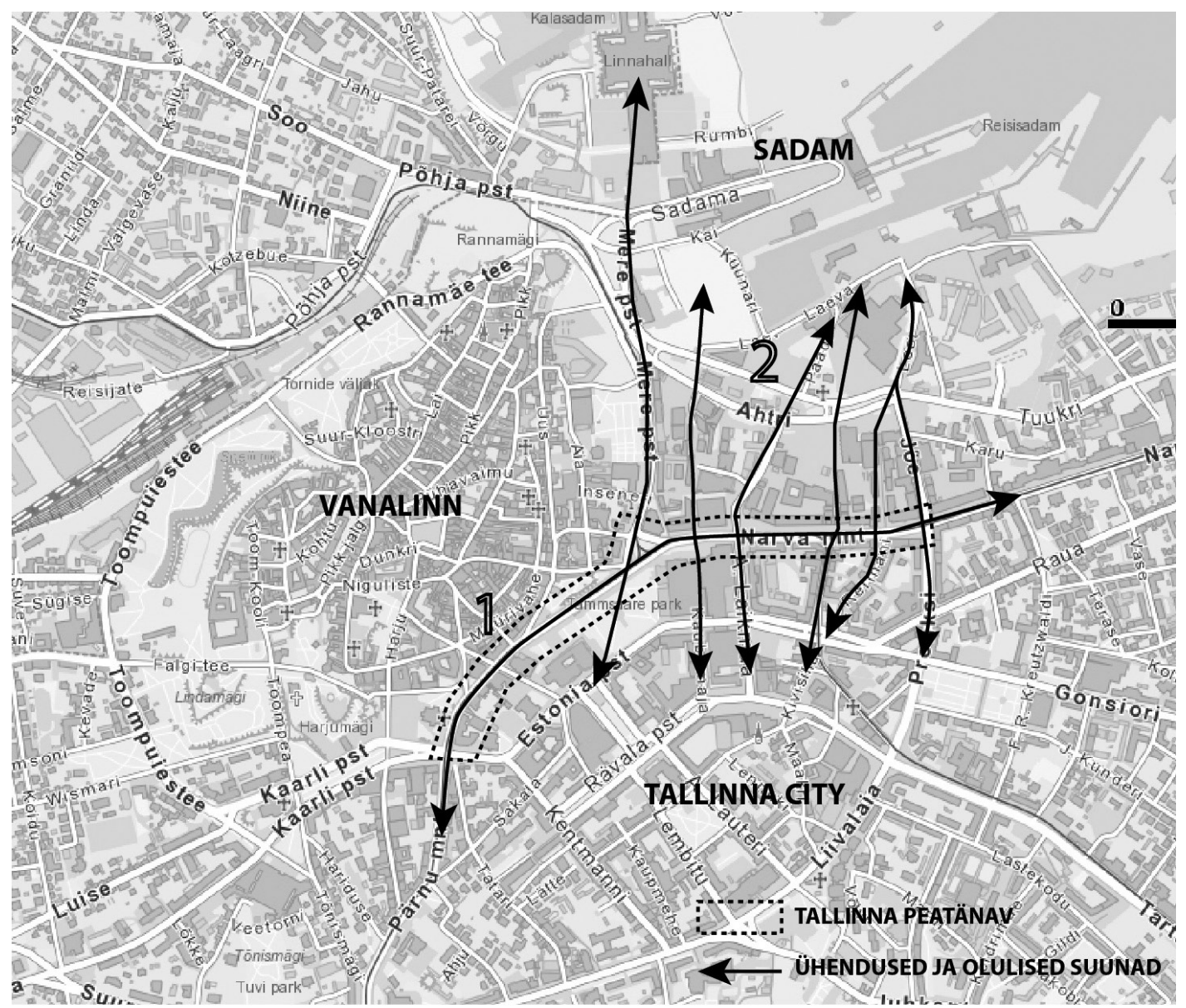

FIGURE II.6.2 Schematic plan of the "Main Street" area. Source: Estonian Centre of Architecture.

Hence, the "Main Street" project was called forth to seek solutions for the redesign of an urban area with limited space for pedestrians, with an exception in one section locating the city park next to the opera house and a theatre building on one side of the road. The place is perceived as a fragmented jungle of disconnected opportunities to enjoy the abundance of cultural, public and commercial services, yet impossible to escape due to the presence of these opportunities as well as public transport nodes connecting the centre and other parts of the city. Always crowded with too few crossings, the narrow pavements walkable but not inviting for strolling or staying (Gehl, 2006) this anonymous space, unavoidably open to everyone, even democratic by nature (Zukin, 1995, p. 11), currently lacks the ambience of the oeuvre (cf. Lefebvre, 2008) in the very heart of the city.

Recognising the potential of the corridors of passers-by to be transformed into attractive public spaces of open opportunities for being, convenient consuming or doing business by creating a clean, environmentally sound, safe and user-friendly urban atmosphere for pedestrians and cyclists, combined with public transport and calmed-down car traffic provided with smooth flows of movements between different places of interest, shaped the core of the imagination and inspired the conceptual approach of the project. 
The "Main Street" project was co-initiated by the City of Tallinn and the Estonian Centre of Architecture (a non-governmental organisation) in cooperation with the Estonian Union of Architects and the Ministry of Economic Affairs and Communications during 2013-2015. The primary funding agencies were the Estonian state, the City of Tallinn, and European structural and investment funds; smaller contributions were made by different research funds as well as companies substantially active in the area. Conducted in two phases, the project broadly involved:

1. The research phase, together with two architectural competitions and discussions at City Forums from 2016 to 2017.

2. The implementation phase, to be started in 2018 and completed in 2019-2020 (currently put on hold). ${ }^{2}$

This chapter primarily discusses the modes of knowledge production in the research phase of the project, intersected with considerations on inter- and transdisciplinary approaches to understanding the urban in terms of creating an experience of high-quality life in shared city space.

Regarding the complexity and scale of the project and the importance of its promise of creating a sustainable strategy to develop urban public space, the chapter comments on how the project was designed and communicated between the research parties involved in the first phase of the project, as well as how it was introduced to and received by wider audiences of citizens. Critical reflections are also provided on a rewarding but challenging experience of urban sociologists and practising architects collaborating in an interdisciplinary qualitative joint inquiry into business actors' selfperceptions and dispositions towards anticipated spatial changes on the site. The analysis of this shared experience linking academia and practice is supported by ex-post interviews with leading architects from the Estonian Centre of Architecture and Tallinn City Planning Department. Selfreflexive analysis of this experience allows the authors, as consultants and researchers, as well as participants in a series of open forums that have also continued beyond the project, to be constructively critical in their accounts on the exchange and transfer of knowledge and, in particular, the conditions observed to enable the advancement of interdisciplinary and transdisciplinary urban research.

\section{Underlying Considerations}

The questions echoing a challenge, as expressed by the coordinator of the "Main Street" project, have been only confirmed in ex-post comments of professionals and practising architects involved in the project. There was a lot of ambition and yet uncertainty before launching the project, with no previous experience to rely on. Especially due to the historical societal path from the 20th to the 21 st century - the 50-year occupation period and socialist planning ideology, followed by the burst of developer-centred urban development after the regaining of independence and the return to the capitalist system from the 1990s onwards - public-sector interventions on this scale were fairly new in Estonia until the "Main Street" initiative. The approach taken in the "Main Street" project raised high expectations, as this new city planning strategy to redesign public space was believed to be truly "groundbreaking," as the winner of the architectural competition also avows (Kauge, 2017, p. 28), ${ }^{3}$ endorsing the project coordinator's assertion of this attempt to have reached the "brink of a paradigm shift" (Sild, 2017, p. 28). 
The assumptions behind these assessments demonstrate the profundity of the planned transformation of the city's central public space as well as the unanimity of agreement found between the different institutions involved, and in particular, the unprecedented scale of new research-based knowledge produced in the first phase of the project, extending beyond the familiar planning and architectural practices. As asserted by the leading architects:

"City planning is sometimes arbitrary. [...] Different city departments deal with their own business, have their [own] data but this is not brought together in a cooperative manner. [...] [Usually] there is not enough research or transdisciplinary collaboration between practices and disciplines."

"There was more information from research than ever before prior to the architectural competitions. An entirely unique project, not business as usual!”

The Chief Architect acknowledges that the amount of knowledge from research rather complicated the setting down of the conditions/terms for the architectural competition, ${ }^{4}$ which, instead of the quotidian practice of addressing single buildings, was extraordinary in its content and scale of redesigning public space.

A series of research projects conducted by experts and academics from different fields as well as discussion forums involving wide audiences of stakeholders with entrepreneurs and representatives of neighbourhood associations among them all served the architectural competitions and the potential decisions to be made for the implementation phase.

There was obviously some perception of the complexity of the "Main Street" project, which demanded complex thinking to be supported by complex knowledge. On the conceptual level, the project builds on an understanding of the need to draw upon an integrated approach along two intertwined basic aspects: first, an acknowledgement of the socio-physical nature of space as an ultimate condition to be considered when redeveloping urban public space; and second, joining together expertise for the production of knowledge as a precondition for a successful redesign of the area. Aiming at transforming public space in resilient design terms, the project pursued liberating space (cf. Smith, 2003) and creating conditions that enable enjoyable and sustainable life in the city. However, as also asserted elsewhere: "it is easier to build cities than urban life" (Stanek, 2014, p. xxvii). ${ }^{5}$ The enjoyment of space in Lefebvrian terms, which seems to be continuously relevant, does not arise from the object per se but from the encounter with the object (Lefebvre, 2014). In other words, to create the urban space of the desired oeuvre, we need to gain perception through insights into the socio-spatial practices, aspirations and actions of different actors and interest groups present in the city. This is to study and understand the dynamic between the materiality and sociality in the creation of quality public space by elucidating the dual, reciprocal nature of ways that space and architectural objects in space are attributed symbolic meanings, which, while informing action, are constructed in actual and imaginative spatial practices (Paadam \& Ojamäe, 2012; Paadam, Siilak, \& Ojamäe, 2014; Paadam, Siilak, \& Gromark, 2017). Striving for in-depth understanding assumes a "feel for the game" (Bourdieu, 1994; 1998; cf. 1993), an inclination towards learning about the unknown by allowing research-informed imagination of the possible to embrace the fixed and flexible, as well as the unpredictable and spontaneous (cf. Stanek, 2014; Madanipour, 2017) inscribed in the nature of public space. It is asserted that this disposition seems 
to have also characterised the approach taken by the leading architects of the "Main Street" project. The perception of the need to incorporate multidisciplinary and transdisciplinary knowledge into reconceptualising public space in the city centre, and a later attempt to conduct a project in an interdisciplinary perspective, indicate an innovative turn in the Estonian planning culture. As has been argued elsewhere, "the orientation towards innovation may, of necessity, engender a pragmatic approach to the challenge of fostering interdisciplinary research" (Barry \& Born, 2014, p. 17). This is regardless of the process in "Main Street" having started with a search for expertise from other disciplines close at hand.

\section{The Legacy of Experience}

The "Main Street" project leaders admit that while setting up the core group of practising architects, planners and a couple of mobility specialists, they went down known paths and did not incorporate academics into the project, as this was felt unnecessary in the first instance. Neither was there a comprehensive research programme. Nevertheless, the research programme was gradually being shaped and expanded along the perception of the need for individual research projects. With the emerging availability of funding, the research was then commissioned from different universities and research institutions. The 12 research projects in total predominantly focused on different aspects of modelling traffic schemes, public transport and mobility of cyclists and pedestrians, also connecting their potential with the business environment and city branding as well as environmental pollution and related health issues. The research programme remained relatively modest in terms of the study of citizens - an important stakeholder group whose perceptions, practices, needs and expectations would have been an essential source of information to reconceptualise such a crucial issue as public space in the central location. As also asserted elsewhere, architectural design works, and hence spatial practices, would benefit from the knowledge and know-how about society through the residents' "skills" incorporated into thinking "with them and not for them" (Mendes and Sá, 2017, p. 48 on Pinson, 2007). The citizens, as "non-experts" in specific disciplines or fields of human conduct, drawing on their daily experience, are increasingly valued for their contribution to knowledge production, adding to its accountability (Weszkalnys \& Barry, 2014, p. 196) as active agents and hence a potential of transdisciplinarity (Novotny, 2004, p. 15). The counter-argument from one of the leading architects draws specifically on professional skills, which the people outside the field do not possess:

"Although I am not sure about [the] involvement of inhabitants... this is a complicated process to generate something that does not yet exist [...] It often happens that people do not understand or trust your ideas before the project is completed and visible. Only then can you involve them by research."

A brief flash survey on user views in the area hardly compensated for the missing, more substantial research. It was later commented by the project leaders that in-depth research on citizens could not be included into the overall research plan, nor added at later phases of the research period, partly due to not acknowledging the need and partly due to limited funding opportunities. The information on citizens' views was hoped to be collected by an open web forum - the Stickyworld platform (http://peatanav.ee/motle-kaasa), which, however, did not meet expectations as public participation remained insignificant. 
It is thus argued that although a number of discipline-based studies conducted in the frame of the research programme were rich in new information and produced considerable knowledge primarily to serve architectural competitions, they left the competitive teams of architects on their own and relying on their subjective experience-based imagination of citizens' preferred spatial practices, with no input from specific social science research.

In ex-post interviews, one of the leading architects agreed with the critique on the part of the authors of this chapter that projects on urban (re)development would benefit considerably more if designing the knowledge production phase embraced a wider disciplinary representation regarding the involvement of the expertise of social scientists. As is seen from the quote below, the entire research phase became a learning process for the initiators of the project:

"At first, we could not imagine that we [would] need such in-depth research. But now when ideas on the development of the heart of the city have advanced [in interactive communication across disciplines], I think sociologists should be engaged from the very beginning."

Likewise, preparatory discussions among research teams would put the multiple research projects of different profiles into a more consistent perspective. In the "Main Street" project, communication between different research groups was limited to the City Forums or special events introducing individually produced research results to groups of stakeholders. City Forums that took place during the research phase were per se enlightening and educating occasions that enabled exchange between academia and practice as well as to learn about one another's ways of perceiving and conceiving of the urban development. Enhancement of exchange between different research groups throughout the research process would enable emergence of the synthesis of interdisciplinary and transdisciplinary knowledge and be in the interests of collaboration between academia and practice. The only exception in a series of multidisciplinary studies was a qualitative inquiry on business actors' perspectives, which, by combining knowledge from architecture and urban sociology, attempted an interdisciplinary approach on the initiative of the managing team of architects (to be discussed later in this chapter). However, in this study, there was a strong twofold element of transdisciplinarity, represented by practising architects and the involved managerial staff of businesses active in the area.

Lefebvre's salient suggestion (2008, pp. 150-151) that only combining disciplinary knowledge can take us closer to comprehensive understanding of the urban is by no means outdated:

"The architect, the planner, the sociologist, the economist, the philosopher or the politician cannot out of nothingness create new forms and relations. More precisely, the architect is no more a miracle worker than a sociologist. Neither can create social relations, although under certain favourable conditions they help trend to be formulated [to take shape]. [...] [They] can individually or in teams clear the way [...] And also [and especially], through a maieutic nurtured by science, assess acquired experience, provide a lesson from failure and give birth to the possible."

The debate on urban space - "a meeting point" for different disciplines - has been evolving with varying intensity since more than half a century ago, continuously articulating the necessity, possibility and capacity to cooperate on an interdisciplinary basis (Stanek, 2011, pp. 136-137). ${ }^{6}$ 
As recognised and clearly stated, individual disciplines can no longer be considered to be able to cover the complexity of the urban (cf. Schaffer, 2014 on Bayoumi \& Rubi, 2000). This argument is more pertinent in the modern circumstances of the uncertainty of social life, economy and politics, calling for conceptual instruments to be continuously designed with reflexibility and growing interdisciplinary cooperation (Mendes and Sá, 2017, p. 47).

Despite these acknowledgements, a number of recent contributions yet again raise concerns about the applicability of interdisciplinary or transdisciplinary approaches by stating, for example, that "the current research landscape around the urban is marked by 'structural holes'; that is, distinct disciplinary clusters of research and practice exist in isolation and are insufficiently linked" (Iossifova, Gasparatos, \& Doll, 2018, pp. 294-295). This is despite the overall growing awareness and understanding of the benefits of taking the trouble to work in an interdisciplinary manner. It is suggested that to reach a new quality of transdisciplinary research and practice paradigms, different disciplines and practices need to be encouraged into collaborative activities on the emerging in-between areas in urban research (ibid.).

\section{Searching Close By and Beyond Boundaries}

There is, certainly, evidence of how disciplines of greater proximity, e.g. architecture and engineering, are relatively more inclined to look for a joint path, as in the experience of "Main Street." But, as seen from the recent research, there is still space for advancement even in these close fields of research and practice. As has been argued, the search for connecting points to tackle the complexity of interdisciplinary practice should start from the actual education: “It is the universities' task to lay the foundations in academic education to overcome the aggregated barriers that arise from a lack of understanding among architects, engineers and urban planners (authors' emphasis) for the responsibility and competences of the respective other groups" (Bögle, 2016, p. 10).

Collaboration is relatively more complicated where there is an attempt to introduce and join knowledge between apparently more distant and distinct academic disciplines, more so between the practices based on specific academic and distinct disciplinary research fields, e.g. architectural practice and sociological research. This is also claimed by one of the project managers of "Main Street":

"An average architect does not even imagine that sociologists could be of use in urban planning. Our education has not supported acquiring an understanding of how society functions - the direct relationship between architecture and sociology. We miss the tradition of taking interest in [these issues][...] Everyone lives in their own box and communicates their own thing. [...] Therefore, we invite people [to join the project] that we know think the way we do."

Mendes and Sá (2017, p. 47) argue that urban planning in particular needs greater participation from social sciences, but this assumes recognition on the part of architects as well as greater openness on the part of social scientists in the search for concrete answers to the needs of projects. The authors emphasise the importance of dialogue in modern urban science, posing a challenge to teachers and researchers working at the crossroads between architecture and the social sciences (ibid.). In many a case, the links between more distant disciplines are less developed for the encountered ontological as well as epistemological distinctions that are characteristic of specific disciplines (Weszkalnys \& Barry, 2014, pp. 196-198). 


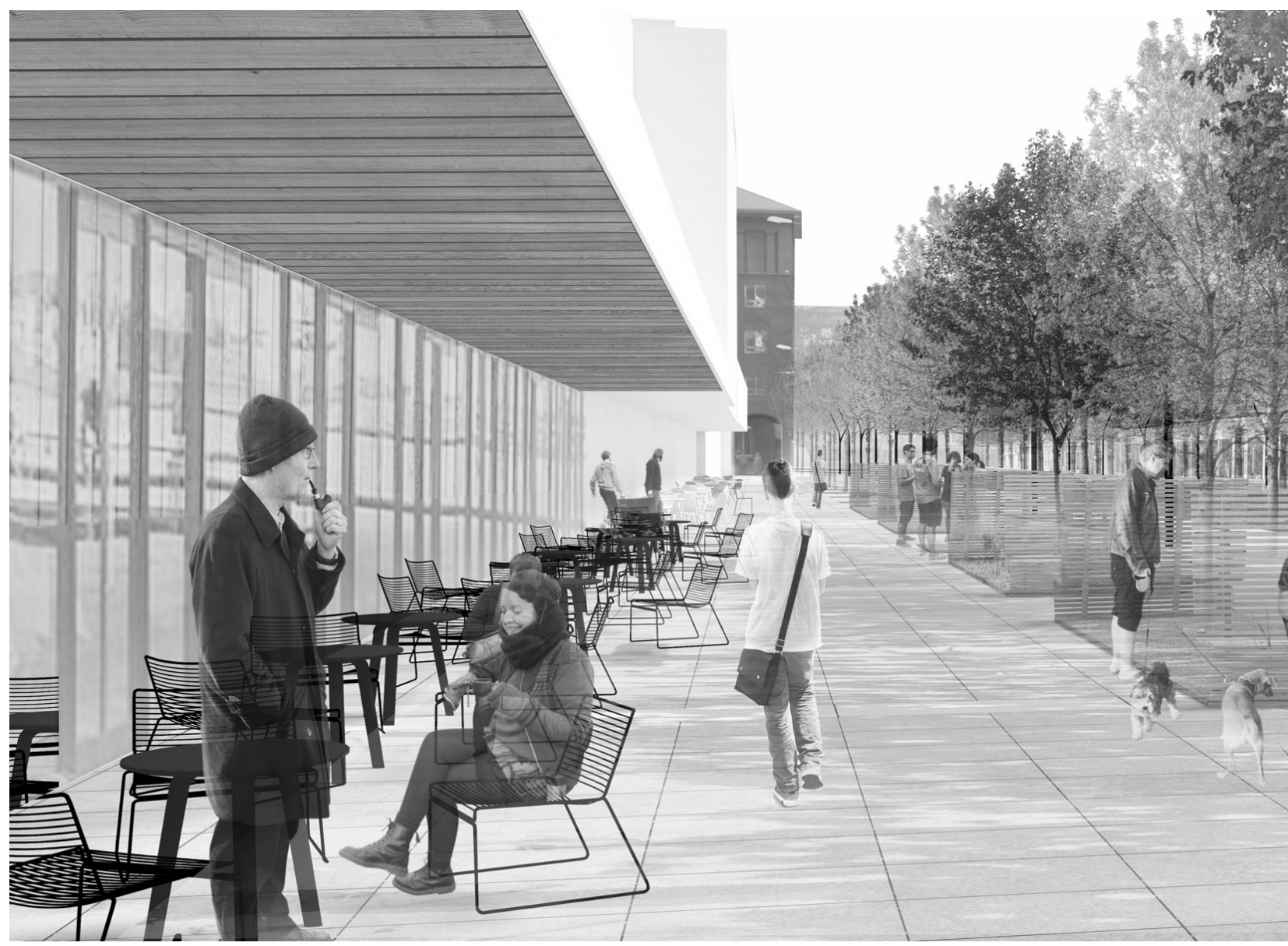

FIGURE II.6.3 3D visualisation of a streetscape in "Main Street" area. Winning project of the architectural competition by Kavakava Architects, Linnalahendused, Extech Design. Source: Estonian Centre of Architecture; Kavakava Architects.

However, aside from intellectual barriers, there are also institutional (either academic or public) obstacles that favour disciplinary rather than interdisciplinary or transdisciplinary research and are reinforced by non-supportive funding programmes or political indifference, as admitted also by the "Main Street" project managers.

"Generally speaking, for politicians, urban planning is not a popular topic; 95 per cent usually take no interest in these matters."

These cross-culturally acknowledged continuous tendencies in academia and daily practice of urban governance are more curious in light of many a recent European Union policy document and research funding programme, which encourage inter- and transdisciplinary approaches to be applied in policies and research in the search for sustainable urban futures, for example the United 


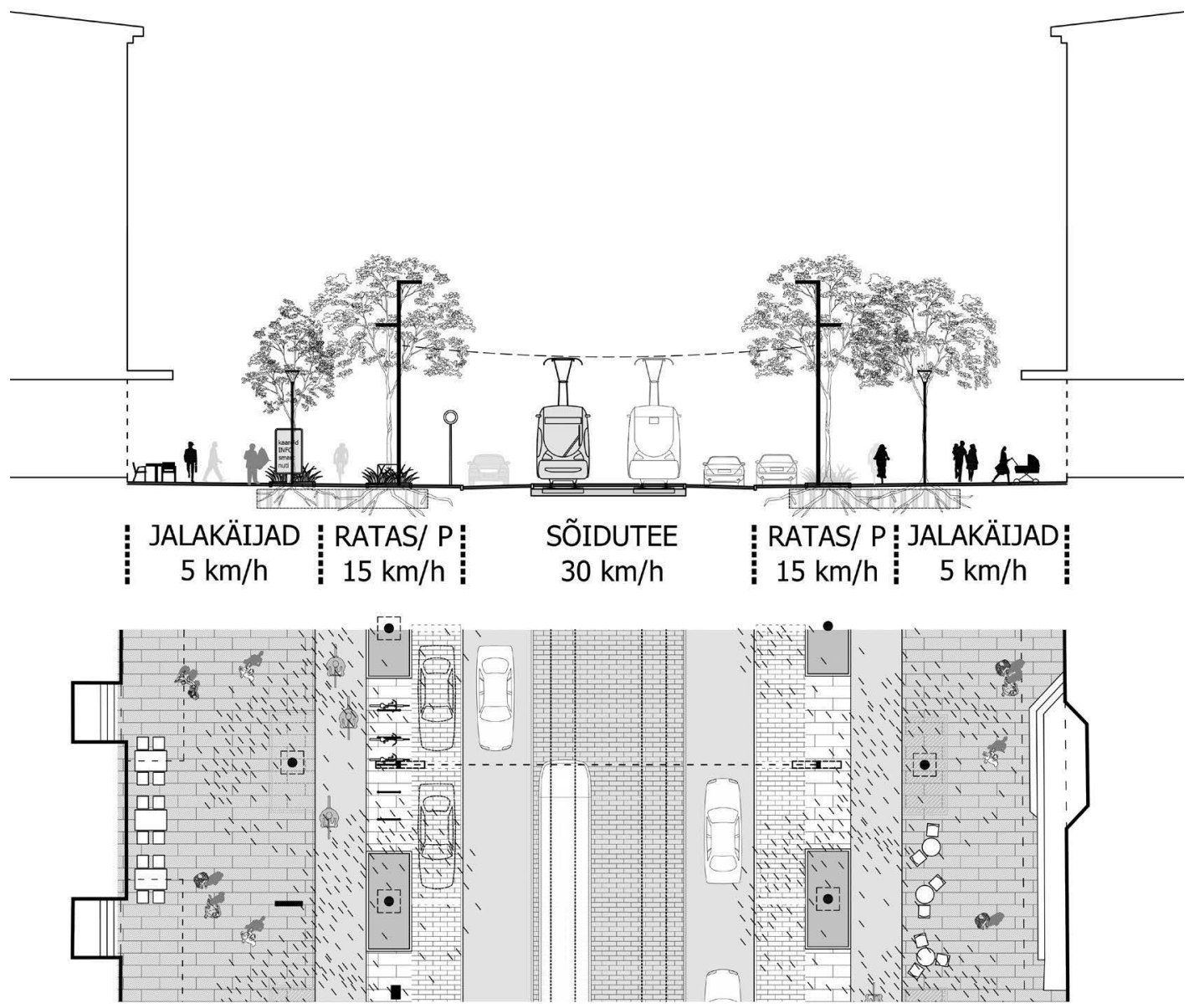

FIGURE II.6.4 A cross-section of a streetscape in "Main Street" area. Winning project of the architectural competition by Kavakava Architects, Linnalahendused, Extech Design. Source: Kavakava Architects.

other. The leading architects, though, admit that while they have been fortunate in timing the project introduction in the period prior to the local elections, the project received attention from only some top politicians. Already with some deep-rooted scepticism about politicians' modest interest from previous experiences, they, however, highly appreciate "the engagement and substantial support of the Mayor of Tallinn," and believe in the prospective benefits that the communication of the project idea has brought to urban society on a wide scale.

"'Main Street' was the first project that was brought into political discussion. Naturally, the elections were looming and it was a good moment to show support. But it was profitable for both sides [the politicians and the project] [...] because the project directly influenced our thinking about opportunities the urban [public] space can offer."

Nevertheless, the project is considered to have had a broadly "positive image" and was successfully 
communicated by the professional media agency that was hired. The two architectural competitions gained particular attention; more so because the implementation of the proposed redesign plans would have affected everyone present or visiting or driving through the area.

As observed in the research experience, the idea of major renewal of the central public space became especially inspiring for the main business actors in the area, informing further development of their businesses and engagement in continued public discussions. In June 2017, the leading business actors in the area initiated and funded another City Forum after the completion of the research phase of the "Main Street" project which focused on the redevelopment of the central area of the city on a larger scale. The City Forum was conceptualised by the Estonian Centre of Architecture. This somewhat unanticipated move coming from the practice may be viewed as an encouraging contribution to the continuation and advancement of inter- and transdisciplinary approaches to be applied in urban research and planning practice.

\section{Experimenting by Joining Competences}

Judging from recent experience, it is asserted that inter- and transdisciplinary collaboration has a potential in the case of creative, constructive and friendly interactions between the project management and research team(s), when there is willingness to learn about and exchange different methodological understandings as well as to experiment and develop new methods and data generation techniques across disciplinary expertise (e.g. architecture-sociology). This collaboration, however, is not entirely uncomplicated. As acknowledged, we are bound to our disciplinary paradigmatic and methodological structures, respective expertise and, no doubt, identities (cf. Durham DeCesaro \& Sharp, 2016 on Baldwin, 2007), which tend to affect flexibility as well as the courage to initiate this type of research endeavour. Concerning primarily the institutional disciplinary conventions, which need to be overcome, though not ignored, Durham DeCesaro and Sharp emphasise the role of involved individuals, motivated by "facilitating learning" in order to facilitate "transformative change" in joint research (ibid.).

The qualitative study with the main business actors in the "Main Street" area, conducted jointly by urban sociologists and practising architects, was a challenge approached from a threefold motivational basis: (1) to achieve comprehensive understanding (knowledge as an ultimate goal in the project context and its potential for implementation) of the accounts of significant stakeholders' own perceptions of the current circumstances in the area, their interest in and expectations of potential changes as well as their strategic dispositions towards area redevelopment; (2) to test the combination of different disciplinary expert tools; and (3) to exchange, learn and elicit opportunities for inter- and transdisciplinary research.

Equipped with our different discourses and disciplinary knowledge, yet with similar intentions to produce substantial new knowledge that contributed to the idea and realisation of the redesign of the area, the sociologists' task was to design the conceptual framework and the interview plan, to produce the analysis of the data generated, as well as to "teach" the architects about their request concerning the procedures in the actual joint interview situation. ${ }^{7}$ Several discussions were held prior to the beginning of interviews and in between different interviews, which in each case combined the talks with visual materials provided by architects. This approach enabled business actors' direct engagement in knowledge production by expressing their experiential in situ percep- 
tions and imagining the potential future. All interviews were conducted in on-site offices of the businesses concerned. The architects' ex-post reflections were overly appreciative of face-to-face interviewing, which for them was a novel experience that qualified as a valued learning process, both about business people as partners in urban planning and design, as well as about themselves as representatives of the profession:

"Transcriptions alone do not tell you about the real dispositions. You perceive this by being present, the facial expressions, tone of voice, emotions. Can this be achieved from a distance? [...] To learn about businessmen's positive attitude, their sense of participation... [...] It is important to get to know these people personally and to learn from these meetings the very practical issues you need to consider [in the urban planning project]. [...] With some enthusiasts of good architecture, they have much stronger connections with the world of architecture than we could have imagined. And you understand that quality space is also in the interests of their business - a guarantee of success. And their success affects the quality of public space. To understand - this is the question! If you get into a conflict with these people you are finished!”

Hence, the involvement of stakeholders such as businesses in the location proved to be a matter of two-way communication. This approach helped to define the problems in the area and the expected solutions. It enabled informing the businesses about the spatial opportunities and potential limitations that accompanied redevelopment plans, as well as listening to and taking their views and concerns into account. It is asserted that instead of building barriers, in-depth engagement of stakeholders into the research enables the avoidance of potential misunderstandings or conflicting situations or even resistance on the part of those concerned. But, most importantly, this joint research cast light onto the potential of transdisciplinarity in urban research and practice.

Concerning joint practice methods, our observations, however, suggest that despite sharing similar values and beliefs in the idea behind the "Main Street" redevelopment project or preexisting mutual trust from earlier positive professional encounters between the research partners (as in our case), there is no guarantee that the jointly conducted research entirely meets the expectations of both parties. This is regardless of the sociologists' and architects' talks, discussions and negotiations on the research instrument conducted in the co-design phase of the research. As the architect comments:

"This research was very useful! [...] [But] the outcome is less concrete than I expected. [...] The research results must be translated to architects. I am a practitioner, I am interested in concrete things, like where exactly a lamp-post should stand."

It has to be admitted that this experience was also a learning process for the sociologists; in particular, the concerns of designing the method of applying a mixed research tool in the same research procedure conducted jointly with architects. The team of urban sociologists was experienced in making use of visual materials in interviews, but this time it was different due to the presence of the architects. Different disciplinary experiences became explicit in the ways that interaction was conducted between the interviewers and interviewees with the use of visual materials. To put it simply, compared with sociologists, architects tend to rely more on "plans put on the table" than 
on verbal expressions. This difference was not noticed during the intensive and in many ways rewarding interview situation, but rather afterwards, when it was discovered that some information was missing from the transcripts. The interviews were only audio recorded and the need for video recording could not have been foreseen. Nevertheless, the important data generated about business actors' main dispositions towards the area redesign from the transcriptions and follow-up inquiries on detailed plans conducted by architects allowed the analysis to provide essential new knowledge.

This experiment, acknowledged as a positive experience by both the architects and sociologists, showed, however, that to enable the production of particular interdisciplinary knowledge on urban situations, considerably more time and in-depth discussions have to be devoted to introductions to and exchanges on disciplinary interests and expectations, capacities and specific methodological knowledge, and - by no means the previous research experiences - before entering the arena of an actual research situation.

\section{A Hope for the Future: Concluding Remarks}

As has been consistently stated in this chapter, the production of knowledge on this scale prior to the implementation of urban redevelopment plans is hardly a normalised strategy in the Estonian planning process. Yet, this innovative approach taken in the context of the "Main Street" project has been a promising experience for all the involved professionals, researchers and various stakeholders in the city, as public space in its multiple dimensions is everyone's matter of interest.

The project, which was initially designed from a multidisciplinary perspective, evolved with experience and acknowledgement of the demand for more complex knowledge produced by transdisciplinary and interdisciplinary research. It has been asserted by the initiators and managers of the project that although the ideas behind "Main Street" have perhaps not reached every group in society or policymakers, it has "set a quality standard to strive towards" and "has already changed the principles of designing urban public space." Despite the current city government's decision to postpone the implementation of the project for the next five years, it is hoped that the "ideas of intervention explicit in the winning project of the architectural competition are not disappearing for good" and will be re-encountered for the sake of creating sustainable conditions for enjoyable urban life.

\section{Acknowledgements}

The authors of this chapter are sincerely grateful to Raul Järg and Tiit Sild, the architects and leaders of the "Main Street" project (Estonian Centre of Architecture) and Endrik Mänd, the Chief Architect of the City of Tallinn for their reflections on the experience of this complex endeavour taken to redesign public space at the heart of the city and to take a wider view of urban planning.

\section{Notes}

1 Tallinn is the capital city of the Republic of Estonia with 441,062 inhabitants; 1 August 2019, https:/ www.tallinn.ee/est/Tallinna-elanike-arv.

2 In 2018, after the local elections, the new city government decided to put the project on hold: first, for additional inquiries on the feasibility of the redesign plan of the central transport scheme in the location and, in particular, its impact on a larger network of city streets; and, second, due to the need to complete the unfinished road projects in the city. This downturn in the project programme clearly expresses changed political priorities and recent alterations in power positions at the municipal departments. 
3 Interview with architect Siiri Valner, a member of the winning team of the "Main Street" architectural competition.

4 The open architectural competition on the public space redesign was the responsibility of the city's Planning Department.

5 A quote from Gaviria's introduction to the Spanish translation of Lefebvre's Right to the City in L. Stanek, Introduction: A manuscript found in Saragossa: Toward an architecture. In: Lefebvre, H. (2014) Toward an architecture of enjoyment. Minneapolis: University of Minnesota Press.

6 L. Stanek on a series of discussions held on interdisciplinarity in urban research in France in the 1960s and 1970s.

7 A number of interviews were later independently conducted by the architects because of the late start of the project and the time planned for interviews was running out for the sociologists.

\section{References}

Barry, A. and Born, G. (eds.). Interdisciplinarity. Reconfigurations of the Social and Natural Sciences. London and New York: Routledge.

Bourdieu, P. (1993). The Field of Cultural Production. Essays on Art and Literature. Cambridge: Polity Press.

Bourdieu, P. (1994). In other words: Essays towards a reflexive sociology. Cambridge: Polity Press.

Bourdieu, P. (1998). Practical Reason. On the Theory of Action. Cambridge: Polity Press.

Bögle, A. (2016). The professional reality is interdisciplinarity! In: Bögle, A., Gieron, S., Kasting, F., \& Peselyte-Schneider, K. (Eds.) Think the link: At - over - on the water 1, pp. 10-18. Hamburg: HafenCity University.

Durham DeCesaro, G., \& Sharp, E.A. (2016). Ordinary wars: Doing transdisciplinary research. Champaign, IL: Common Ground.

European Commission. (n.d.). Policy themes: Urban development. Retrieved 04 October 2019 from https:// ec.europa.eu/regional_policy/en/policy/themes/urban-development/.

Gehl, J. (2006). Life between buildings: using public space. Copenhagen: Danish Architectural Press.

Iossifova, D., Gasparatos, A., \& Doll, C.N.H. (2018). Defining the urban: A quixotic pursuit. In: Iossifova, D., Doll, C.N.H., \& Gasparatos, A. Defining the urban: Interdisciplinary and professional perspectives, pp. 283-296. London: Routledge.

Kauge, J. (2017). Persoon: Siiri Vallner, ratsionaalne boheemlane/Persona: Siiri Vallner, rational bohemian. MAJA: Estonian Architectural Review, 1-2/2017(89-90), 62-71.

Lefebvre, H. (2008). Writings on cities. Malden, MA: Blackwell Publishing.

Lefebvre, H. (2014). Toward an architecture of enjoyment. Minneapolis: University of Minnesota Press.

Madanipour, A. (2017). Cities in time: Temporary urbanism and the future of the city. London: Bloomsbury.

Mendes, M.M., \& Sá, T. (2017). Interdisciplinary relations between social sciences and architecture: Tensions, ambiguities and complementarities. In: Mendes, M.M., Sá, T., \& Cabral, J. (Eds.). Architecture and the social sciences: Inter- and multidisciplinary approaches between society and space, pp. 33-50. Cham, Switzerland: Springer International.

Novotny, H. (2004). The potential of transdisciplinarity. In: Dunin-Woysethand, M., \& Nielsen, M. (Eds.). Discussing transdisciplinarity: Making professions and the new mode of knowledge production, pp. 1018. (The Nordic Reader 2004). Oslo: AHO, The Oslo School of Architecture and Design.

Paadam, K. and Ojamäe, L. (2012). Tallinna Linnavalitsuse uue hoone kavandamisest lähtuv mereäärse lähiala kujunemine ja sellega seotud kasutajagruppide hinnangud ja hoiakud. Tallinn: Tallinn University of Technology. Retrieved 10.10.2019 from https://www.tallinn.ee/est/g8312s61549.

Paadam, K., Siilak, K., \& Gromark, S. (2017). The experience of converted spaces in Tallinn: Symbolic change and becoming of identities. In: Gromark, S., Ilmonen, M., Paadam, K., \& Støa, E. (Eds.). Ways of residing in transformation: Interdisciplinary perspectives, pp. 77- 101. London: Routledge.

Paadam, K., Siilak, K., \& Ojamäe, L. (2014). Elamiskogemuses väärtustatud linnaruum. Tallinn: Tallinn University of Technology. Retrieved 10.10.2019 from https://www.tallinn.ee/est/ehitus/Infomaterjalid-jaettekanded. 
Schaffer, S. (2014). How disciplines look. In: Barry, A. \& Born, G. (Eds.). Interdisciplinarity: Reconfigurations of the social and natural sciences, pp. 57-81. London: Routledge.

Sild, T. (2017). Tallinna Peatänav/Tallinn Main Street. MAJA: Estonian Architectural Review, 3/2017(91), $20-27$.

Smith, N. (2003). Foreword. In: Lefebvre, H. The urban revolution, pp. vii-xxiii. Minneapolis: University of Minnesota Press.

Stanek, L. (2011). Henri Lefebvre on space: Architecture, urban research, and the production of theory. Minneapolis: University of Minnesota Press.

Stanek, L. (2014). Introduction. A manuscript found in Saragossa: Toward an architecture. In: Lefebvre, H. Toward an architecture of enjoyment, pp. xi-lxi. Minneapolis: University of Minnesota Press.

Weszkalnys, G., \& Barry, A. (2014). Multiple environments: Accountability, integration and ontology. In: Barry, A. \& Born, G. (Eds.). Interdisciplinarity: Reconfigurations of the social and natural sciences, pp. 178-208. London: Routledge.

Zukin, S. (1995). The cultures of cities. Cambridge, MA: Blackwell. 